\title{
Views of Senior Nursing Students on the Problems of the Elderly During the Covid- 19 Process and Attitudes Against Ageism
}

\author{
Kamuran ÖZDIL ${ }^{1}$, (iD Gülhan KÜÇÜK ÖZTÜRK², (iD) Aslıhan ÇATIKER², (iD) Gizem Deniz BULUCU BÜYÜKSOY ${ }^{4}$
}

${ }^{1}$ PhD. Lecturer Aged Care Program, Nevsehir Hacı Bektaş Veli University, Health Services Vocational School, Nevşehir, Turkey

${ }^{2} \mathrm{PhD}$. Research Assistant, Department of Psychiatric Nursing, Nevşehir Hacı Bektaş Veli University Semra and Vefa Küçük Faculty of Health Sciences, Nevşehir, Turkey

${ }^{3}$ Asst. Prof. Lecturer Department of Nursing, Ordu University Faculty of Health Sciences, Ordu, Turkey

${ }^{4}$ Asst.Prof. Department of Nursing, Kırşehir Ahi Evran University Faculty of Health Sciences, Kırşehir, Turkey

\begin{abstract}
Background: Older adults, the prevalence of chronic diseases increase, depending on the physiological and psychological changes that occur with aging processes of maintenance issues in pandemic seems to be more important. Objectives: This study aims to examine the attitudes of senior nursing students regarding ageism as well as their views of the problems the elderly faced during the COVID-19 pandemic. Methods: The present study is a mixed study with quantitative and qualitative dimensions and it was conducted in the nursing department of a health sciences faculty in Turkey. The quantitative part of the study consisted of 75 senior students and the qualitative part was composed of 13 students. Quantitative data were collected using the Introductory Information Form and the Ageism Attitude Scale and qualitative data using a semi-structured interview form. Descriptive statistics, independent samples t-test, one-way analysis Mann-Whitney U, and Kruskal-Wallis tests and content analysis were used. Results: The mean age of the students was $22.16 \pm 0.91,76 \%$ were female, $85.3 \%$ lived in the same house with an older adults in the pandemic process, $96 \%$ provided nursing care to the older adults during their professional education, and $18.7 \%$ did help the older adults during the pandemic. It was found that the students' attitudes toward the elderly were positive and their views of the elderly during the pandemic were distributed among the main themes of Vulnerable, Emotional Shake, Culture, and Iceberg. Conclusion: In this study, it was determined that senior nursing students have a positive attitude towards elderly people and can handle the effects of the COVID-19 pandemic on the health of elderly individuals from a holistic perspective. It is recommended to increase the opportunity of students to care for the elderly in the nursing education process and to include the concept of the elderly more in the nursing curriculum.

Keywords: Ageism, Older Adults, Nursing Students, Pandemics.
\end{abstract}

\section{$\ddot{O} z$}

\section{Hemşirelik Son Sınıf Öğrencilerinin Covid 19 Sürecinde Yaşlıların Yaşadıkları Sorunlara Yönelik Görüşleri ve Yaşlı} Ayrımcilı̆ı̆na Karşı Tutumları

Giriş: Yaşlı bireylerin, kronik hastalık prevalansının artması, yaşlanma ile ortaya çıkan fizyolojik ve psikososyal değişikliklere bağlı olarak bakım sorunlarının pandemi sürecinde daha da önemli olduğu görülmektedir. Amaç: Bu çalışmanın amacı son sınıf hemşirelik öğrencilerinin yaşlı ayrımcılığına ilişkin tutumları ve Covid-19 pandemi sürecinde yaşlı bireylerin yaşadıkları sorunlara ilişkin görüşlerini incelemektir. Yöntem: Bu çalışma nicel ve nitel boyutları olan karma bir çalışmadır ve Türkiye'deki bir sağlık bilimleri fakültesinin hemşirelik bölümünde yürütülmüştür. Araştırmanın nicel bölümünü 75 son sınıf öğrencisi, nitel bölümünü ise 13 öğrenci oluşturmuştur. Nicel veriler; Tanımlayıcı Bilgi Formu ve Yaşlı Ayrımcılığı Tutum Ölçeği (YATÖ) ile, nitel veriler ise yarı yapılandırılmış görüşme formu kullanılarak toplanmıştır. Nicel verilerin değerlendirilmesinde tanımlayıcı istatistikler, independent sample t test, One Way Anova, Mann-Whitney U ve Kruskal Wallis testleri; nitel verilerin değerlendirilmesinde de içerik analizi yöntemi kullanılmıştır. Araştırmanın uygulanabilmesi için, etik kurul izni ve katılımcı onamı alınmıştır. Bulgular: Araştırmada öğrencilerin yaş ortalaması $22.16 \pm 0.91$ olup \%76.0'sının kadın olduğu, \%85.3'ünün pandemi sürecinde yaşlı biri ile aynı evde yaşadığı, \%96'sının mesleki eğitimleri sürecinde yaşlı bireye hemşirelik bakımı verdiği ve \%18.7'sinin pandemi sürecinden yaşlı bireye yardım ettiği saptanmıştır. Araştırmada öğrencilerin yaşlı bireylere yönelik tutumlarının olumlu olduğu ve öğrencilerin pandemi sürecinde yaşlılara ilişkin görüşlerinin savunmasızlık, duygusal sarsıntı, kültür ve buzdağı ana temaları çerçevesinde dağılım gösterdiği belirlenmiştir. Sonuç: Bu çalışmada, son sınıf hemşirelik öğrencilerinin yaşlı bireylere yönelik tutumlarının olumlu olduğu ve COVID-19 pandemisinin yaşlı bireylerin sağlığı üzerindeki etkilerini bütüncül bakış açısıyla ele alabildikleri belirlenmiştir. Buna göre öğrencilerin hemşirelik eğitim sürecinde yaşlılara bakım verme firsatının artırılması ve hemşirelik müfredatında yaşlı kavramına daha çok yer verilmesi önerilir. Anahtar Kelimeler: Yaşı Ayrımcılığı, Yaşı Yetişkinler, Hemşirelik Öğrencileri, Pandemiler.

Geliş Tarihi / Received: 28.01.2021 Kabul Tarihi / Accepted: 18.08.2021

Correspondence Author: PhD. Lecturer Kamuran ÖZDIL Aged Care Program, Nevsehir Haci Bektaş Veli University, Health Services Vocational School, Nevşehir, Turkey. Telefon: +90 3842281000 (14027) E-posta: kamuranozdil2008@ gmail.com

Cite This Article: Özdil K, Küçük Öztürk G, Çatıker A, Bulucu Büyüksoy GD. Views of Senior Nursing Students on the Problems of the Elderly During the Covid 19 Process and Attitudes Against Ageism Dokuz Eylül Üniversitesi Hemşirelik Fakültesi Elektronik Dergisi. 2021; 14(4): 357- 369 
$\mathbf{C}$ OVID-19 is a disease caused by the newly identified coronavirus in China, in December 2019. Because of this virus' unique properties, COVID-19 rapidly spread around the world and created a public health emergency at a global level. Indeed, the World Health Organization (WHO) declared a pandemic associated with COVID-19 on March 11, 2020. As of July 13, 2020, there were 12768.307 confirmed COVID-19 cases worldwide, including 566.654 deaths, reported to the WHO database (1-4).

While the spread of COVID-19 around the world has created a serious public health crisis, the resulting data demonstrated that the individuals with an underlying disease and the older adults were at high risk of infection. It was also determined that the rates of severe diseases and mortality increased with age $(1,5,6)$. The WHO reported that this situation is of great importance, especially for countries with a large older adults population and that those countries will be inevitably affected by the pandemic. In Europe, 30,098 people have died because of COVID-19 and 90\% of the deaths have occurred in Italy, Spain, and France. It has been found that more than $95 \%$ of the people who died were aged 60 years and above, and more than $50 \%$ were aged 80 years and above (7). The older adults population in our country is growing steadily. It was noted that the proportion of the older adults population in Turkey in total population has increased from $8 \%$ in 2014 to $8.8 \%$ in 2018 (8). Given the growing older adults population in Turkey, the pandemic, which is a serious problem worldwide, is expected to pose a serious risk for the older adults in Turkey. It has been reported in the literature that being old is an important risk factor in dealing with the social problems and health risks brought about by the pandemic (9-11).

Despite unknown aspects of COVID-19, the existing confirmed information is extremely crucial for public health and the development of clinical treatment $(7,12)$. This information shows us that the protection of older adults individuals from COVID-19 and their access to healthcare is a priority. The efforts to combat COVID-19 with an emphasis on the older adults should be considered with an extensive perspective including early diagnosis, treatment, comorbidity, polypharmacy, adequate ventilation, and physical and psychosocial issues, especially social stigma $(13,14)$. Discriminatory discourses, superstitions, and unfounded information about whether various ethnic groups and races would be affected by the disease in the early days of the disease spread faster than the outbreak in the press and social media (15). It is reported that Asians who are traveling, emergency response teams, healthcare workers, and older adults may be subject to stigma due to COVID-19. Older adults are exposed to higher risks because of not only poverty and social exclusion in all societies but also their mental health $(13,16,17)$. The dissemination of insulting expressions targeting the older adults - a sign of resentment between generations - as well as hate discourse in social media, incidents such as employees' refusing to work at nursing homes in some countries when intergeneration solidary is most needed, are important as regards understanding violations of human and patient rights of the older adults (16).

It is known that the lockdown measure, experienced by the older adults during the pandemic, is the most basic method for protecting them from infection. In most countries, restrictions were introduced on visits to nursing homes, and individuals over the age of 65 years were asked to stay at home to reduce physical contact with others and thus minimize the risk of infection. In this context, some restrictions were imposed on the older adults by a circular of the Ministry of Internal Affairs of Turkey on March 21, 2020. The circular in question covers individuals over the age of 65 years with various chronic diseases who use drugs for these reasons. Under the circular, certain restrictions have been imposed regarding the older adults leaving their residence, visiting open spaces, parks, using public transport, or going out into the street. For ensuring that the older adults needs can be meet during this period, "Vefa" social support groups were established in Turkey with the participation of representatives of public institutions and organizations, local governments, the Disaster and Emergency Management Presidency (AFAD), the Turkish Red Crescent, and nongovernmental organizations, determined by province/district police chiefs, province/district gendarmerie commanders, and governors/district governors. On May 17, 2020, the older adults were allowed to go out into the streets at certain hours in Turkey (18).

In the literature, it is stated that the effect of the Covid-19 pandemic process on physical, mental and social problems due to restrictions in older adults has increased $(11,19,20)$. It is known that the discrimination that older adults are exposed to, especially in the first months of the pandemic, is among these problems $(21,22)$. Despite this negative discrimination, examples of positive discrimination emphasizing the behavior of helping the older adults were observed (23). Covid-19 pandemic; It has been a process in which many ethical dilemmas and conflicts have been experienced towards the older adults, and this process has made the vulnerabilities of the elderly more visible in all societies (24). In Spain, nursing home residents were left to die and there were failures to care for vulnerable groups in a global crisis (25). In Australia, the United Kingdom, and the United States, accusations were common in attributing adjectives to the elderly during the pandemic (26).

Nurses are at the forefront of providing care to individuals, families, and communities in all communities during endemic and pandemic times (27). Nurses can be leaders in protecting the health of the older adults, who are especially vulnerable and at high risk of frailty, and in the fight against ageism (28). Increasing the quality of elderly care services is closely related to having a positive attitude towards the elderly. It is stated that the attitudes of nurses and health workers who provide primary health care services towards the elderly are positive in the Covid-19 pandemic and that the attitudes of health workers towards the elderly should be improved in order to increase the quality of healthcare services for the older adults (29). Undoubtedly, the improvement and development of the attitudes of health workers towards the elderly should be addressed in the process of vocational training (30). It is thought that determining the attitudes of nursing students, who are health professionals of the future, towards ageism, is a prerequisite for the development of care services to be offered to older adults. Evaluating older adults health problems from the perspective of nursing students and determining their attitudes towards ageism can contribute to older care in nursing education, 
especially in global health crises such as pandemics.

\section{Aim}

This study aims to examine the attitudes of senior nursing students towards ageism and their views on the problems experienced by the older adults during the COVID-19 pandemic.

\section{Research Questions}

- What are the effects of the COVID-19 pandemic process on the health of the older adults from the perspective of nursing students?

- What are the opinions of nursing students on the factors affecting the health of the older adults in the COVID- 19 pandemic process?

- What is the level of ageism among nursing students

\section{Study Type}

\section{Methods}

The present study is a mixed methods research that includes a descriptive survey of senior nursing students who took the geriatrics course and individual in-depth interviews to determine the current situation. The study's steps are summarized in the flow chart (Figure 1).

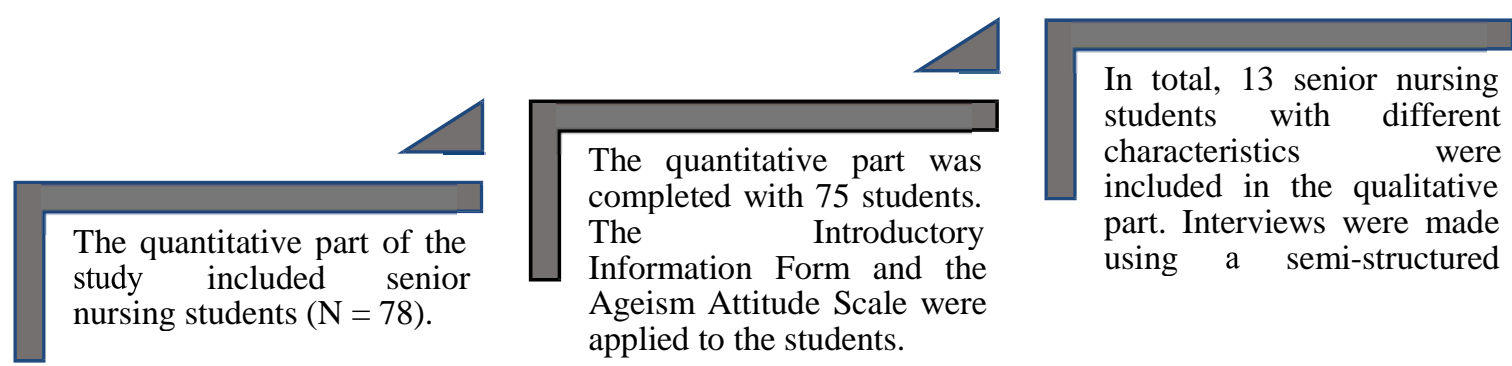

\section{Figure 1. Research Diagram}

\section{Study Population and Sample}

The population of the quantitative part of the study consisted of the senior nursing students who attended the Nursing Department of the Faculty of Health Sciences at a university in Turkey in 2019-2020 academic year and who took the geriatrics course (elective course) $(\mathrm{N}=78)$. No sample was selected. The quantitative part of the research was completed with 75 students. Because of the analysis, it was found that the descriptive characteristics of the students and their ageism total and sub-scale mean scores were similar and they had a positive attitude toward ageism (Table 1).

As there is no specific sample size to satisfy in qualitative studies, the data collection process is terminated when concepts and expressions begin repeating (saturation point) in a way to provide answers to the research questions (31). The study was completed with 13 students.

\section{Inclusion criteria for study group and Exclusion criteria}

All students who agreed to participate in the study were included in the quantitative part of the study. In the qualitative part, students living in different settlements (province/district/village), living with individuals over the age of 65 (home, neighbor, neighborhood) during the pandemic process, and caring for individuals over the age of 65 (home, neighbor, neighborhood, etc.) during the pandemic were included. Students who do not have these characteristics were excluded from the study.

\section{Variables of the Study}

The independent variables of the research; students' gender, residence, family structure, living in the same house with an elderly person during the pandemic, providing nursing care to the elderly person in vocational training and helping the elderly person during the pandemic process. The dependent variables are; Age Discrimination Scale total scores.

\section{Data Collection Tools}

The quantitative data of the study were collected with the Introductory Information Form and the Ageism Attitude Scale. A. Introductory Information Form: This form comprises fifteen questions to determine the sociodemographic characteristics of the students and their life with the older adults during the pandemic. $(32,33)$. While eight of them were related to the sociodemographic characteristics of the students, seven were related to the elderly and the Covid-19 process.

B. Ageism Attitude Scale (AAS): This scale was developed by Vefikuluçay (2011) and its validity and reliability study was conducted (Cronbach's alpha reliability coefficient of 0.80 ). The scale consists of 23 items and three dimensions. Items $1,5,12,14,17,19,21,22,23$ belong to the sub-dimension of limiting the life of the elderly. Items 2, 4, 6, 7, 8, $9,13,20$ belong to the sub-dimension of affirmative action towards the elderly. Items $3,10,11,15,16,18$ belong to the sub-dimension of negative discrimination against the elderly. There is no item calculated in reverse. It is a 5-point Likert-type scale with expressions related to the older adults. The degree of agreement with the positive attitude statements toward ageism is marked between "Strongly agree" (5) and "Strongly disagree" (1); the higher the scores 
obtained from the scale, the higher the degree of positive attitude toward ageism. The highest score from the scale is 115 and the lowest is 23 . Moreover, this scale consists of three sub-scales: restricting the life of the older adults, positive ageism and negative ageism; the higher the score from the scale, the higher the degree of ageism in each sub-scale (34). In this study, the Cronbach alpha value was 0.77 .

The qualitative data of the study were collected with a semi-structured interview form.

A. Semi-structured Form: This form contains open-ended questions designed to determine the opinions of the nursing students on the status of older adults during the COVID-19 pandemic.

B. Semi-structured Interview Questions

- How do you evaluate the COVID-19 pandemic for the older adults?

- How do you think the COVID-19 pandemic has affected the health of the older adults?

- What do you think about the factors affecting the health of the older adults during the COVID-19 pandemic?

- Is there anything you would like to add in this regard?

\section{Data Collection}

The quantitative data collection tools were prepared digitally as an online form. To ensure the comprehensibility of the questions in this form, a preliminary application (six students) was conducted. The form was finalized by making the necessary corrections. Online forms were designed so that the participants could fill it out only once. In the online form, information was provided about the study purpose, and the participants were asked to provide consent to participation in the study in a separate field. The data were collected between June 10 and 15, 2020, by sending the link via online communication networks.

The qualitative data were collected between June 15 and 30, 2020, with a semi-structured interview form. As formal education was interrupted during the pandemic, the data were collected using a program that allowed interviews to be conducted online. The students in the sample group were contacted via telephone; they were then informed about the research and their consent was obtained in the online form. Interviews were conducted with each student separately. The day/hour for the interview was determined considering the availability of each student. A researcher who had not taught the geriatrics course conducted the interviews; this was done to eliminate various negative factors such as student orientation and grade anxiety. The interviews were recorded and they lasted for 30-40 minutes.

\section{Data Evaluation}

The quantitative data were analyzed through a computer using number, percent, mean, standard deviation, median, independent samples t-test, one-way analysis of variance, and Mann-Whitney U and Kruskal-Wallis tests.

The qualitative data were first digitized and then evaluated by content analysis. The data of the study were divided into categories by four researchers by coding, and then, themes and subthemes were determined by uncovering relationships between categories. Themes and sub-themes were evaluated by taking the experts opinion and finalized (31).

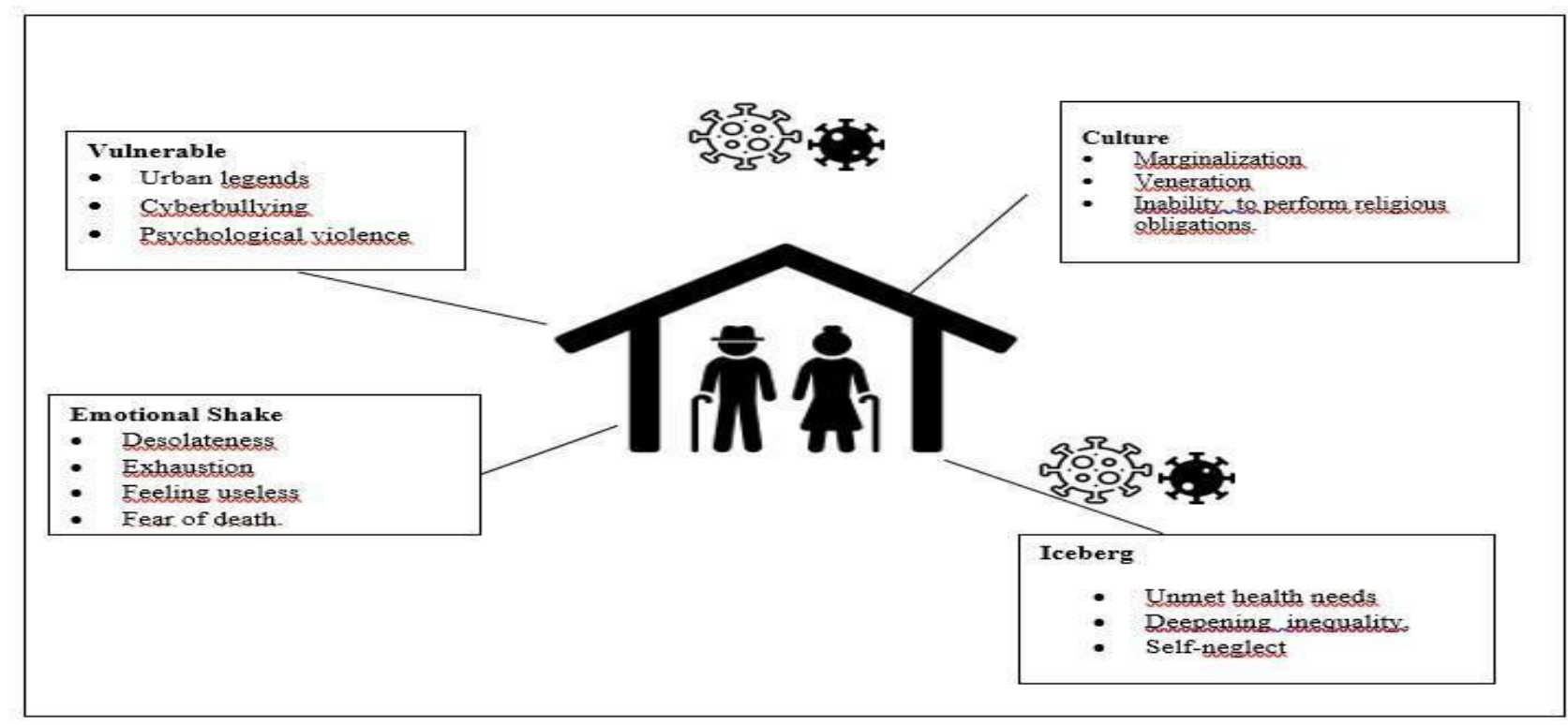

Figure 2. Themes Emerging from the Interviews

*Sources of images used in figures (35)

\section{Trustworthiness}

In this study, trustworthiness was achieved through long-term interviews, participant confirmation, and expert examination methods. Before starting the negotiations, a reassuring communication environment was provided between the researcher and the participants. Necessary information was provided and attention was paid to collect the data as long as possible. To minimize the researcher bias, the interviews were not conducted by the researcher who conducted the geriatrics course. At the end of the interview, the data were summarized and the participants were asked for their opinions about their accuracy. Finally, they were also told that they could include any additional comments/opinions. 
Then, expert opinion was sought about the interview forms before they were finalized. Two experts who had training and experience in qualitative research were consulted regarding the themes identified by the researchers during the data analysis and these themes were finalized. To ensure validation, interview notes as raw data in the study as well as notes on the respondents' statements were taken during the interview, and the participants' statements were included directly in the research report. In the study, the transferability criterion is satisfied as the participants had characteristics for being used in similar sample groups in different communities in terms of inclusion criteria and their detailed introduction.

\section{Ethical principles}

Before starting the research, the approval of the Scientific Research Board of the Ministry of Health (2020-0511T17_25_04.xml) and the ethics committee approval (Decree no: 2020.12.120) from Nevşehir Hacı Bektaş Veli University were obtained. The purpose of the research was explained to the participants both and written online consent was acquired from the participants for participation in the research. The names of the participants are kept confidential. The study conforms to the Declaration of Helsinki.

\section{Quantitative Findings}

\section{Results}

The mean age of the students was $22.16 \pm 0.91,76 \%$ were female, $57.3 \%$ lived in the center, $76 \%$ lived in nuclear families, $85.3 \%$ lived in the same house with an older adults in the pandemic process, $96 \%$ provided nursing care to the older adults during their professional education, and $81.3 \%$ did not help the older adults during the pandemic. It was found that the participating students associated the concept of old age with compassion (74.6\%), wisdom (64\%), illness $(60.0 \%)$, loneliness $(53.3 \%)$, weakness $(50.6 \%)$, dependence $(40 \%)$, mental decline (28\%), commitment $(25.3 \%)$, happiness $(13.3 \%)$, and isolation $(13.3 \%)$.

The scores that the students got from the AAS scale and its sub-dimensions are presented in Table 1. The distribution between AAS scores and introductory characteristics of the students was examined. No statistically significant difference was found between AAS mean scores and the gender, residential unit, family structure, living in the same house with an older adults person during the pandemic, giving nursing care to the older adults in the professional education, and helping the older adults during the pandemic $(\mathrm{p}>0.05)$. (Table 1). It was found that the students had similar introductory characteristics as well as AAS total and sub-scale mean scores, and their attitudes were positive.

Table 1. The Distribution of Ageism Attitude Scale Score, and Subscale Scores of The Students (n=75)
Scales
$\operatorname{Mean} \pm S D$
Median (Min-Max)

\begin{tabular}{llc}
\hline AAS total score mean $\pm \mathrm{sd}($ min-max) & $88.13 \pm 8.08$ & $70-102$ \\
\hline Limitation of life total score mean $\pm \mathrm{sd}$ & $36.22 \pm 3.16$ & $17-40$ \\
\hline Positive discrimination mean $\pm \mathrm{sd}$ & $32.08 \pm 4.48$ & $13-28$ \\
\hline Negative discrimination mean $\pm \mathrm{sd}$ & $19.82 \pm 3.68$ & 28
\end{tabular}


Table 2. Distribution of Students Based on AAS Total and Sub-scale Mean Scores by their Introductory Characteristics $(n=75)$

\begin{tabular}{|c|c|c|c|c|c|c|}
\hline Characteristics & $\mathrm{n}$ & $\%$ & $\begin{array}{l}\text { AAS } \\
\text { Total }\end{array}$ & $\begin{array}{l}\text { Limitation } \\
\text { of Life }\end{array}$ & $\begin{array}{c}\text { Positive } \\
\text { Discriminati } \\
\text { on }\end{array}$ & $\begin{array}{c}\text { Negative } \\
\text { Discriminati } \\
\text { on }\end{array}$ \\
\hline Gender & & & $p=0.308$ & $p=0.154$ & $p=0.525$ & $p=0.220$ \\
\hline Female & 57 & 76.0 & $t=1.034$ & $t=1.465$ & $z=-0.635$ & $z=-1.227$ \\
\hline Male & 18 & 24.0 & & & & \\
\hline Residential unit & & & $p=0.216$ & $p=0.457$ & $p=0.408$ & $p=0.307$ \\
\hline Province & 43 & 57.3 & $F=1.566$ & $F=0.791$ & $K W=1.792$ & $K W=2.362$ \\
\hline District & 23 & 30.7 & & & & \\
\hline Village & 9 & 12.0 & & & & \\
\hline Family type & & & $p=0.437$ & $p=0.237$ & $p=0.287$ & $p=0.980$ \\
\hline Nuclear family & 57 & 76.0 & $t=-0.787$ & $t=-1.193$ & $z=-1.065$ & $z=-0.025$ \\
\hline Extended family & 18 & 24.0 & & & & \\
\hline \multirow{2}{*}{\multicolumn{3}{|c|}{$\begin{array}{l}\text { Living in the same home with an older adults so } \\
\text { far }\end{array}$}} & $p=0.396$ & $p=0.239$ & $p=0.520$ & $p=0.783$ \\
\hline & & & $t=0.854$ & $t=1.189$ & $z=-0.643$ & $z=-0.276$ \\
\hline Yes & 31 & 41.3 & & & & \\
\hline No & 44 & 58.7 & & & & \\
\hline \multicolumn{3}{|c|}{$\begin{array}{l}\text { Living in the same house with an older adults in } \\
\text { pandemic }\end{array}$} & $\begin{array}{l}p=0.790 \\
t=-0.272\end{array}$ & $\begin{aligned} p & =0.475 \\
t & =0.736\end{aligned}$ & $\begin{array}{l}p=0.787 \\
z=-0.271\end{array}$ & $\begin{array}{l}p=0.614 \\
z=-0.504\end{array}$ \\
\hline Yes & 11 & 14.7 & & & & \\
\hline No & 64 & 85.3 & & & & \\
\hline \multicolumn{3}{|c|}{ Nursing care for the older adults } & $p=0.799$ & $p=0.946$ & $p=0.253$ & $p=0.869$ \\
\hline Yes & 72 & 96.0 & $t=-0.289$ & $t=0.077$ & $z=-1.194$ & $z=-0.190$ \\
\hline No & 3 & 4.0 & & & & \\
\hline \multicolumn{3}{|c|}{ Helping an older adults in the pandemic process } & $p=0.633$ & $p=0.736$ & $p=0.638$ & $p=0.722$ \\
\hline Yes & 14 & 18.7 & $t=0.443$ & $t=0.343$ & $z=-0.471$ & $z=-0.355$ \\
\hline No & 61 & 81.3 & & & & \\
\hline
\end{tabular}

\section{Qualitative Findings}

The age of the students interviewed in this study ranged from 21 to 33 years. Of the students interviewed, 10 were female and 3 were male. The study revealed 4 themes and 13 subthemes of nursing students' opinions concerning the older adults during the COVID-19 pandemic, as shown in Figure 2. The main themes were Vulnerable, Emotional Shake, Culture, and Iceberg.

\section{Theme 1: Vulnerable}

Based on the analysis of the interviews, it was determined that all students perceived the older adults as vulnerable in the pandemic and their perceptions were categorized under three subthemes: urban legends, cyberbullying, and psychological violence.

a. Urban legends: Many students stated that during the pandemic, there was a perception in society that the older adults were a danger, rather than fragile, in terms of the disease. In particular, the students noted that certain distorted information and stories about the older adults had been circulating in society, and because of lack of knowledge, these urban legends quickly spread.

"The introduction of the lockdown for those 65 years of age in the pandemic process, I think, created negative thoughts both in the older adults and in members of society, and stories were told as if the older adults were spreading microbes" (S4, female).

"It was thought that the older adults were spreading the virus in the pandemic, but the truth is that the older adults are infected more quickly, and it's hard for the older adults to fight it if they are infected. This was actually due to lack of knowledge in society" (S5, female, with emphasis).

b. Cyberbullying: All the students stated that the older adults were exposed to numerous bullying behaviors via TV and/or social media. It was seen that the students considered this cyberbullying as ageism and stigma. They also stated that these acts of cyberbullying upset both the older adults and themselves.

"In social media, the older adults were ridiculed, and disrespectful videos were filmed. It was both shameful and very sad. For example, my grandmother had to go to the doctor. Even though the doctor called her, she didn't go to see the doctor, saying that people would think ill of her in the street. She was very upset" (S2, female).

"I saw a video on Instagram. They saw an old man out in the street, and, in an effect to alarm him, they said to him, 'What are you doing out there? We're gonna call the police right now.' This upset me as a young person, and it must upset the older adults and their families even more" (S4, female).

c. Psychological violence: Some students stated that the older adults were exposed to psychological violence during the pandemic process. 
female).

"When the older adults went out in society, people shouted at them, 'What are they doing out there?", (S1,

"I know a case in which they chased the old man with a stick and said to him, 'The virus came out because of you.' I think such situations must have hurt them very much" (S2, female).

\section{Theme 2: Emotional Shake}

Almost all the students indicated that the older adults experienced an emotional shake because of COVID-19. They associated emotional shake particularly with the subthemes of desolateness, exhaustion, feeling useless, and fear of death.

a. Desolateness: Majority of the students stated that the loneliness of the older adults increased during the pandemic because they were required to stay at home, stay away from their environment and their families, and often went through this process on their own.

"Loneliness of the older adults increased partially due to the concerns of getting infected. They were unable to meet their relatives, grandchildren, children, etc., and they felt lonely and desolate" (S5, female).

"The older adults want to chat with someone because they feel abandoned. My grandmother was anxious to chat with her neighbors, relatives, etc., although she knew the risks of the virus. I think the social and mental health of the older adults who tried to go through this process alone was seriously affected" (S4, female).

b. Exhaustion: Some students stated that the older adults were feeling overwhelmed by the pandemic, and as they were trapped in the house, they felt exhausted.

"The pandemic is already a very delicate process for the older adults. The measures introduced caused their exhaustion further. Especially their mental health..." (S2, female).

"The older adults could engage in action through such activities as going to the market, walking, but they were trapped in the house during the pandemic. Many old individuals expressed that they were overwhelmed just by sitting at home. They do not exercise at all, and they ate frequently due constant drowsiness or boredom at home. This affected their physical health" (S4, female).

c. Feeling useless: There were students who noted that the older adults were distracted from many activities that they could engage themselves in daily life and that was productive. They expressed that this distancing made the older adults unhappy and feel useless.

"Before the pandemic, my grandmother would go to her village, grow tomatoes, cucumbers, etc., collect, and eat them. She couldn't get there due to lockdown, and her diet changed a lot. She was upset to see the tomatoes from the market were not like the tomatoes she would grow. And my grandmother used to walk in order to get a little tired and sleep easily. During the pandemic, she never got tired, and her sleep regime was disrupted" (S2, female).

d. Fear of death: Almost all the students stated that the type of fear felt most by the older adults during the pandemic was the fear of death.

"There was too much fear of death among the older adults. I was watching TV with my grandmother, and she saw those who died of coronavirus were calcified before burial. And she said, 'I hope I won't die because I don't want it to be buried that way'" (S3, female).

"My grandmother talked about death all the time. Already there was a fear of death in the older adults and the coronavirus increased it. I've seen a lot of older adults around me who were worried they're gonna get infected" (S7, male).

\section{Theme 3: Culture}

Almost all the students mentioned culture as an important determinant of older adults health during the pandemic. The students referred to culture under the subthemes of marginalization, veneration, and inability to perform religious obligations.

a. Marginalization: The students stated that they saw the worldwide tendency to treat the older adults as second-class citizens as a major problem.

"Many countries have excluded the older adults and prioritized the treatment of younger people. This practically means leaving the older adults to death. This is definitely a very bad situation for them" (S11, male).

"Patients who need respiratory support were categorized as older adults and young patients in other countries during the pandemic. They even preferred to give respirators to young patients. When the older adults heard the news, they had a great anxiety that 'they would treat us like this'"' (S12, male).

"When we look at the world, the older adults were the first group discarded in many countries in order to reduce the burden on healthcare and intensive care" (S13, female).

b.Veneration: Some students stated that one of the most important features of Turkish culture was veneration of the older adults, and this was affected during the pandemic and the intergenerational solidarity was damaged.

"Relations with relatives and neighbors are very important in Turkish culture. Now, the older adults are making special efforts not to meet the neighbors. I do not know if this is temporary, but I think these relations have weakened" (S1, female).

"The exclusion of the older adults from society and their exposure to discriminatory treatment due to lockdown created many social problems that could damage the relationship between generations" (S13, female).

c) Inability to perform religious obligations: Some students stated that the older adults were negatively affected because they were unable to attend worship services during the pandemic, and their daily routines were disrupted and they were unable to perform their habitual activities. 


\begin{abstract}
"Mass worship is my grandfather's favorite. I think spiritual insatiability may result because he cannot worship" (S9, female).

"When the mosques were shut down, they had to take a break from their worship with their friends" (S11,

male).
\end{abstract}

\title{
Theme 4: Iceberg
}

Some students stated that the older adults had to fight many problems during the COVID-19, further indicating that the older adults had to face serious challenges against problems related to healthcare, policies, and/or themselves. The students expressed that these problems looked like an "iceberg" and could be dangerous in the future. They associated them with the subthemes of unmet health needs, deepening inequality, and self-neglect.

a. Unmet health needs: Some students expressed that the older adults had many unmet health requirements during the pandemic, especially primary health services, nursing services, and holistic health.

"For example, the cops went to the old people's homes to give support. Public health nurses could meet the treatment and care services of the older adults with the mobile team. Nursing services were inadequate" (S1, female).

"We have been quarantined for 14 days because of my grandmother, and no health professional has checked us. But in this process, a community health nurse should have come to inform us about when to refer to the hospital" (S9, female).

During the interviews, few students highlighted the need for public health and community mental health services. Moreover, the students indicated that planning should be made for the protection of older adults health and prevention of ageism.

"I think we need to learn from the pandemic and think about what we can do to protect the health of society without referral to hospitals" (S6, female).

"The older adults with chronic diseases had difficulty accessing their medication. If we weren't in my grandmother's life, I don't know who would have brought her medicine. Even the mere anxiety of not being able to access the medication really affects the older adults very negatively" (S4, female).

"My grandmother has cancer, and unfortunately, we were never able to visit her because of the pandemic. She got a fever, and she was hospitalized, and her health deteriorated. For example, if our health services had been developed and if we had been able to offer home care services to every home, this would have been very good for our older adults" (S9, female).

b. Deepening inequality: There were students who stated that the inequalities present in our society against the older adults deepened during the pandemic.

"Support groups tried to meet the needs of the older adults. But they couldn't keep up with everyone. The requirements of the older adults cannot be met only through the support groups..." (S12, male).

"It was already difficult for them to meet their needs, and this process affected them even more negatively. They couldn't go out and get their food, and they couldn't exercise, and they couldn't even get a fresh air... they were constrained at home"(S5, female).

c. Self-neglect: Some students stated that during the pandemic, the older adults began neglecting themselves due to the deterioration of their daily routines and lack of knowledge.

"The daily life activities of the older adults have changed due to coronavirus. They could perform exercises at home for their physical health, or pay attention to their nutrition. But they thought that there was a lack of information and was constantly focused on going out. This, in turn, caused them to have a negative impact on their health "(S6, female).

“Their diet, their sleep patterns, their medication use-they're all mixed up. In general, their routines are broken. They didn't care about it themselves. Maybe, from stress, maybe, I do not know, from age" (S11, male).

\section{Discussion}

Nursing students can be good observers in society with the abilities they acquire during their undergraduate studies for evaluating individuals with a holistic approach, protecting health, and improving and rehabilitating illnesses, if any, and they can serve as good mirrors reflecting the level of health of society. In this study, the opinions of senior nursing students regarding the older adults in the pandemic process and their health status were examined.

Across the world, the COVID-19 pandemic is experienced as a period wherein the importance of health and social systems is recognized, and particular focus has been placed on the number of population groups that are older adults or have a chronic disease in countries as well as their psychosocial needs. The older adults were considered a risk group even before the pandemic. However, during the pandemic, they have become even more vulnerable because of being isolated, economic losses, their inability to access healthcare, stigma, and exposure to discrimination as a result of their exposure to social distance and lockdown, implemented as a public health strategy for limiting the spread of COVID-19 (15,36). It was reported that these events/social events experienced by the older adults who are considered at high risk during the COVID-19 pandemic have led to medical, social, psychological and religious problems (11).

In the quantitative part of the study, it was determined that all students had positive attitudes toward the older adults (Table 1). However, the students tended to associate old age mostly with the concepts of compassion, wisdom, and illness. Furthermore, of the ten concepts voiced by the students, only three — wisdom, commitment, and happinessdescribe an acquisition or a good mood, while the other seven - compassion, illness, loneliness, weakness, dependence, mental decline, and isolation - describe old age as a state of loss and need. Accordingly, it was concluded that the positive attitudes that the students had toward the older adults was not because of them having respect for what the older adults acquired in old age, but because they believed that the older adults deserved extra care, attention, compassion, 
and support out of respect for old age as well their exhaustion and sickness. In the literature, only to be perceived by society of these perceptions and treatment of older adults is not the way, is reportedly also affects how they see treatment by nurses. It has also been noted that older adult patients are worth respecting, and negative and aged attitudes affect the emotional and physical quality of older adults (37). These results show that perceptions about old age are considered a prerequisite for having a positive or negative attitude toward the older adults.

In the interviews conducted in the qualitative part of the study, it was found that the nursing students stated that the pandemic process had made older adults more vulnerable. The reasons for this were listed as unfounded and fabricated information about the elderly that rapidly spread and turned into urban legends, the videos humiliating the older adults posted on social media, and the ensuring psychological violence. Similarly, in the literature, it was reported that the media highlighting COVID-19 as a unique threat had negative effects (15). The students' statements that people believed that the elders were responsible for the spread of the virus and that the older adults were prevented from walking on the street gives an idea of the dimensions of ageism and discrimination against the older adults in Turkish society. The student nurses further indicated that the cultural values of countries had been affected by the pandemic and the culture of veneration toward the older adults weakened because of the risk of infection, urban legends, stigma, and ageism targeting the older adults. Accordingly, it can be said that the cultural characteristics that protected the older adults were damaged during the pandemic. According to a study conducted in Indonesia, the serious increase in the number of COVID-19 cases cannot be prevented only by increasing community awareness regarding the spread of the virus. It was underlined that anti-stigma programs involving community-based approach, elimination of negative perceptions, and giving positive messages should be created to slow down the increase in the number of cases (38).

In the interviews conducted in the study, the students noted that an atmosphere that pushed the older adults into the background emerged because of many reasons such as the existing cultural structure in some countries during the COVID-19 pandemic. The students reported that the older adults were marginalized and that the treatment of younger people was prioritized in some countries. According to the students, this marginalization negatively affected the older adults. Similarly, Burlacu et al. indicated that the older adults suffered increased despair after witnessing that young people were prioritized in the treatment process, and this could lead to fear, anxiety disorders, and depression (11). Asghari et al. studied the community attitudes regarding the groups that should be prioritized in provision of ventilator support in Iran and found that that the participants believed the patients should be monitored periodically and those patients who did not benefit from the device should be disconnected from the device (39).

In the present study, it was found that $41.3 \%$ of the students lived in the same house with the older adults before the pandemic and $14.7 \%$ lived in the same house with the older adults during the pandemic, but no statistically significant difference was found between this situation and ageism. TurkStat (2019) data, the most important source of happiness for the older adults is their families (71.4\%) and children (14.7\%) (8). Although the number of nuclear families have increased owing to the changes in the family structure in Turkey, the traditional family structure and culture is largely still maintained, and as the older adults share the same living environment as well as their experiences with family members especially children and grandchildren, this contributes to the well-being of the older adults. However, in the interviews with nursing students, it was found that during the pandemic, the older adults stayed alone at home because of the lockdown, and as they could not meet with family members or friends, they felt abandoned. Conversely, the older adults live alone in $24.4 \%$ of the households with an older member in Turkey (8). Accordingly, it is likely that the older adults who were living alone before the pandemic might have completely isolated themselves in their homes by staying away from their neighbors and relatives because of lockdown. Similarly, in the literature, it was reported that most policies that required social distancing owing to COVID-19 considered the older adults as the main target group in need of stronger psychosocial support. In particular, it was noted that the elderly were forced to live in long-term isolation, and they did not have social networks and they had limited social activity (40,41). Vieiria et al. studied the impact of COVID-19 and precautionary measures on vulnerable groups and observed that the measures including social distancing were critical in preventing the spread of the virus, but they may have negative effects in the long run and special attention should be paid to the older adults in this context (42).

During the interviews, the students indicated that the older adults had many unmet health needs during the pandemic and social services offered in the country specific to the older adults were inadequate. In a study that examined the effects of social isolation on mental health of the older adults in the pandemic, it was noted that some countries developed strategies specifically for the older adults in social isolation (43). Despite some initiatives targeting the mental health of older adults individuals in Turkey, it is difficult to say that they are large-scale and comprehensive. Studies indicate that Skype, Facetime, telemedicine, and smartphone applications can be used when face-to-face care is not possible during the pandemic (44). However, these practices may not be suitable for the older adults in developing countries, given their basic characteristics such as their level of education, cognitive skills, and socioeconomic status. It is known that approximately half the older adults population in Turkey $(46.1 \%)$ is primary school graduates and the women have a lower education level (8). In this case, it is clear that some innovative strategies are needed for Turkey and countries with similar characteristics. For example, it was reported that the guide developed to ensure that the older adults staying in nursing homes in the Netherlands could be visited had positive effects on the welfare level of the older adults (45).

Various religious practices can be useful in coping with loneliness. Burlacu et al. stated that ways for providing proper care for the protection of the health of the older adults who cannot perform religious practices during the COVID19 pandemic should be found. Religious practices such as participating in church services, praying, and reading spiritual literary publications are strategies that individuals use to cope with daily life stresses (11). It should be noted that the 
reason why older adults need more psychological support during the COVID-19 pandemic than usual is to cope with the pandemic (46). In the present study, it was reported that watching the news reports about the number of COVID-19 related deaths as well the burial process exacerbated the existing fear of death for the older adults, and because they could not go to the mosque because of lockdown, they were deprived of mass worship, an element that allowed them to socialize culturally.

According to the students' opinions, the lockdown, economic losses, loneliness, and poverty during the pandemic have led to a deepening of inequalities against the older adults. In Turkey, $12.5 \%$ of the older adults participate in the workforce (8). The lockdown may have caused the working older adults to be unemployed and suffer economic losses. Moreover, given that $16.4 \%$ of the older adults in Turkey are poor, the pandemic may have made the older adults socioeconomically more fragile (8). All this can increase the need for social services, rehabilitation, and home care services for the older adults both during and after the pandemic period, possibly increasing their mental health care needs. Similarly, it was reported in the literature that the older adults should be particularly supported during this crisis. It is noted that this support may be in the form of making phone calls; meeting their mental, social, and physical health needs; responding to their requests for help; and providing information about where to find support. It was also stressed that the older adults can be supported through extensive social support networks, organized charities, and healthcare workers during the pandemic (47).

Another experience that is as important as living with the older adults in reducing or preventing negative ageism against the older adults is to give care to the older adults throughout nursing education. In the present study, it was found that virtually all students $(96 \%)$ provided care to the older adults in a clinical setting and had positive attitudes toward ageism. Similarly, many studies found that giving care to the older adults in a clinic had a positive effect on the students' attitudes toward ageism (48). According to the opinions of the students, the absence of a nurse in the team that provides services to the older adults during the pandemic, provision of health care only in the hospital with a therapeutic emphasis, and neglecting the preventive aspect of healthcare can increase unmet health needs of the older adults.

According to the interviews, the older adults felt emotionally exhausted as they were no longer able to perform their usual social activities, and they felt useless because they could not be productive. Disruption of the daily routines of the older adults caused them to neglect themselves, resulting in non-compliance with their diet, being physically inactive, disruption of the scheme of taking medications, and not coping with stress, caused by disruption of the management of chronic diseases. In a study, it was reported that the COVID-19 lockdown would reduce physical activity, which might have negative metabolic consequences such as increased insulin resistance, muscle atrophy, and cardiovascular problems. It was also noted that the sudden abandonment of physical activity in the pandemic process could increase sadness, anger, and frustration, making individuals prone to depression (49). It can be said that according to the opinions of the nursing students, as the older adults were faced with many social, economic, and cultural problems during the pandemic, we have not yet been confronted with the greater and more important portion of the health problems of the older adults. Accordingly, in the coming days, we may be faced with many problems related to the elderly such as increasing unmet healthcare needs, complicated psychosocial problems, progression of chronic diseases, and aggravation of mental problems.

Disruption of basic public health services such as providing access to healthcare in emergency situations actively and providing healthcare in a non-discriminatory manner can increase the existing psychosocial problems (e.g., maternal and infant mortality, violence, child abuse and neglect, mental problems, and substance use), which may be exacerbated by the pandemic (50). In the interviews conducted in the present study, the students recommended that primary, secondary and tertiary care should be improved to protect and maintain the health of the older adults and ensure the continuity of chronic disease care.

\section{Limitations}

The study was conducted on intern nursing students at the Department of Nursing, Faculty of Health Sciences, University in a province in X. Therefore, the results of the study are limited to a sample of nursing students studying in the specific province where the study was conducted.

\section{Use of Results in Practice}

In the present study, it was found that senior nursing students had positive attitudes toward ageism and they had important observations and and can handle the effects of the COVID-19 pandemic on the health of elderly individuals from a holistic perspective. The students believed that this pandemic had dramatic consequences for the older adults in many respects. The nursing students expressed that the life and health of the older adults were affected, particularly owing to the approaches or behaviors that made the older adults vulnerable, the emotional shocks created by the pandemic and various cultural factors. Furthermore, the students reported that various existing and/or potential issues, such as the invisible face of the iceberg, would continue affecting the older adults physically, spiritually and socially.

In this study, the nursing students' ability to adopt such a broad perspective in their observations and views regarding older adults and discuss the pandemic in an in-depth manner with a focus on the older adults was associated with them being senior students, their experience of giving care to the older adults, and their taking the geriatrics course. In this respect, the importance of theoretical and practical knowledge given to the prospective health professionals especially regarding the vulnerable groups was understood. Therefore, it is believed that it is important to ensure that health team members who will work with the older adults should be provided with an environment wherein they can provide care to the older adults in the first years of their education. To this end, the existing facilities should be increased and the concept of old age should be discussed in different courses and subjects of the curriculum. 


\section{Acknowledgement}

The authors' contribution rate statement is as follows: research idea KÖ, AÇ, GDBB, data collection, analysis GKÖ, GDBB, AÇ and manuscript writing all authors, study design, manuscript control and editing All authors, all authors approved the final version for submission. Before starting the research, the approval of the Scientific Research Board of the Ministry of Health (2020-05-11T17_25_04.xml) and the ethics committee approval (Decree no: 2020.12.120) from Nevşehir Hacı Bektaş Veli University were obtained. The purpose of the research was explained to the participants both and written online consent was acquired from the participants for participation in the research. The names of the participants are kept confidential. The study conforms to the Declaration of Helsinki. No conflict of interest has been declared by the author(s). 


\section{References}

1. Huang C, Wang Y, Li X, Ren L, Zhao J, Hu Y, Cheng Z, et al. Clinical features of patients infected with 2019 novel coronavirus in Wuhan, China. The lancet. 2020; 395(10223): 497-506. https://doi.org/10.1016/S01406736(20)30183-5

2. Kar SK, Arafat SY, Sharma P, Dixit A, Marthoenis M, Kabir R. COVID-19 pandemic and addiction: Current problems and future concerns. Asian Journal of Psychiatry. 2020; 51: 102064. Advance online publication. https://doi.org/10.1016/j.ajp.2020.102064

3. World Health Organization (WHO). Coronavirus Disease (COVID-19) Dashboard. https://covid19.who.int/ 2020 Accessed 11 May 2020.

4. World Health Organization (WHO). WHO Timeline COVID-19. https://www.who.int/news-room/detail/27-042020-who-timeline---covid-19. Accessed 11 May 2020.

5. Sun N, Wei L, Shi S, Jiao D, Song R, Ma L, et al. A qualitative study on the psychological experience of caregivers of COVID-19 patients. American Journal of Infection Control. 2020; 48: 592-598. https://doi.org/10.1016/j.ajic.2020.03.018

6. Mills JP, Kaye KS, Mody L. COVID-19 in older adults: clinical, psychosocial, and public health considerations. JCI insight. 2020; 5(10): 139292. https://doi.org/10.1172/jci.insight.139292

7. World Health Organization (WHO). Statement - Older people are at highest risk from COVID-19, but all must act to prevent community spread. URL: https://www.euro.who.int/en/health-topics/health-emergencies/coronaviruscovid-19/statements/statement-older-people-are-at-highest-risk-from-covid-19,-but-all-must-act-to-preventcommunity-spread. Accessed 6 May 2020.

8. Turkish Statistical Institute (TurkStat). Elderly with http://www.tuik.gov.tr/PreHaberBultenleri.do?id=33712. 2019. Accessed 18 March 2020

9. Sher L. An infectious disease pandemic and increased suicide risk. Revista brasileira de psiquiatria (Sao Paulo, Brazil : 1999), 2020; 42(3): 239-240. https://doi.org/10.1590/1516-4446-2020-0989

10. Bailey L, Ward M, DiCosimo A, Baunta S, Cunningham C, Romero-Ortuno R et al. Physical and Mental Health of Older People while Cocooning during the COVID-19 Pandemic. QJM. 2021 Jan 20:hcab015. https://doi.org/10.1093/qjmed/hcab015

11. Burlacu A, Mavrichi I, Crisan-Dabija R, et al. "Celebrating old age": an obsolete expression during the COVID-19 pandemic? Medical, social, psychological, and religious consequences of home isolation and loneliness among the elderly. Arch Med Sci. 2020;17(2):285-295.https://doi.org/10.5114/aoms.2020.95955

12. Lloyd-Sherlock P, Şah Ebrahim LG, Martin M. Bearing the brunt of covid-19: older people in low and middle income countries. BMJ. 2020; 368: m1052 https://doi.org/10.1136/bmj.m1052

13. Center for Disease Control and Prevention (CDC). Reducing Stigma Centers for Disease Control and Prevention COVID19. https://www.cdc.gov/coronavirus/2019-ncov/daily-life-coping/reducing-stigma.html. 2020.

14. Jackson D, Bradbury- Jones C, Baptiste D, Gelling L, Morin K, Neville S, Smith GD. Life in the pandemic: Some reflections on nursing in the context of COVID- 19. Journal of clinical nursing. 2020; $2041-2042$. https://doi.org/10.1111/jocn.15257.

15. Jiloha RC. COVID-19 and Mental Health. Epidemiology International (E-ISSN: 2455-7048). $2020 ;$ 5(1): 7-9.

16. Council of Europe. Older persons need more support than ever in the age of the Covid-19 pandemic. https://www.coe.int/en/web/commissioner/-/older-persons-need-more-support-than-ever-in-the-age-of-the-covid19-pandemic.2020.

17. IFFR, UNICEF, WHO. Social Stigma associated with COVID-19. A guide to preventing and addressing social stigma. https://www.who.int/docs/default-source/coronaviruse/covid19-stigma-guide.pdf . Accessed 1 May 2020.

18. Ministry of Interior, Curfew Circulation for 65 Years and Above and Chronic Diseases. Access address: https://www.icisleri.gov.tr/65-yas-ve-ustu-ile-kronik-rahatsizligi-olanlara-sokaga-cikma-yasagi-genelgesi. Accessed 20 June 2020.

19. Owen RK, Conroy SP, Taub N, Jones W, Bryden D, Pareek M, Banerjee J. Comparing associations between frailty and mortality in hospitalised older adults with or without COVID-19 infection: a retrospective observational study using electronic health records. Age and ageing, 2021;50(2):307-316. https://doi.org/10.1093/ageing/afaa167

20. Bello-Chavolla OY, González-Díaz A, Antonio-Villa NE, Fermín-Martínez CA, Márquez-Salinas A, VargasVázquez A, Gutiérrez-Robledo LM. Unequal impact of structural health determinants and comorbidity on COVID19 severity and lethality in older Mexican adults: Considerations beyond chronological aging. The Journals of Gerontology: Series A, 2021;76(3):e52-e59.https://doi.org/10.1093/gerona/glaa163

21. Jen S, Jeong M, Kang H, Riquino M. Covid-Related Newspaper Coverage: The First Month of a Pandemic, The Journals of Gerontology, 2021; gbab102. https: //doi.org/10.1093/geronb/gbab102

22. Parker, J. (2021). Structural discrimination and abuse: COVID-19 and people in care homes in England and Wales. The Journal of Adult Protection.

23. Vervaecke D, Meisner BA. Caremongering and Assumptions of Need: The Spread of Compassionate Ageism During COVID-19, The Gerontologist, 2021;61(2):159-165. https://doi.org/10.1093/geront/gnaa131

24. Swift HJ, Chasteen AL. Ageism in the time of COVID-19. Group Processes \& Intergroup Relations. 2021;24(2):246-252. https://doi.org/10.1177/1368430220983452

25. Rada AG. Covid-19: the precarious position of Spain's nursing homes. Bmj, 2020;369 https://doi.org/10.1136/bmj.m1554 
26. Lichtenstein B. From "Coffin Dodger" to "Boomer Remover": Outbreaks of Ageism in Three Countries With Divergent Approaches to Coronavirus Control, The Journals of Gerontology, 2021;76(4):e206-e212, https://doi.org/10.1093/geronb/gbaa102

27. Lowey S. Withholding Medical Interventions and Ageism During a Pandemic, Journal of Hospice \& Palliative Nursing, 2021;23(3):200-206. https://doi.org/10.1097/NJH.0000000000000737

28. Wilson DM, Nam MA, Murphy J, Victorino JP, Gondim EC, Low G. A critical review of published research literature reviews on nursing and healthcare ageism. Journal of clinical nursing, 2017;26(23-24):3881-3892. https://doi.org/10.1111/jocn.13803

29. Rashedi V, Hasheminejad N, Naghibzadeh-Tahami A, Borhaninejad V. Ageism among primary health care professionals and nurses in Iran. Ethics, Medicine and Public Health, 2021;17:100638. https://doi.org/10.1016/j.jemep.2021.100638

30. Dahlke S, Davidson S, Kalogirou MR, Swoboda NL, Hunter KF, Fox MT, Salyers V. Nursing faculty and students' perspectives of how students learn to work with older people. Nurse Education Today, 2020;93:104537. https://doi.org/10.1016/j.nedt.2020.104537

31. Kyngäs H, Kristina Mikkonen, MK. The Application of Content Analysis in Nursing Science Research. Springer Nature. 2019; 3-11.

32. Bozdoğan Yeşilot S, Yeşil Demirci P, Öztunç G. Hemşirelik Öğrencilerinin Yaşlı Ayrımcılığına Yönelik Tutumları ve Etkileyen Faktörlerin Belirlenmesi . Düzce Üniversitesi Sağlık Bilimleri Enstitüsü Dergisi, 2020;10(1):87-93 . https://doi.org/10.33631/duzcesbed.537976

33. Yilmaz M, İnce FZ. Relationship Between Nursing And Elderly Care Students' attitudes Towards Ageism. Belitung Nursing Journal, 2017;3(4):281-296. https://doi.org/10.33546/bnj.83

34. Vefikuluçay D, Terzioğlu F. Üniversite öğrencilerinde yaşlı ayrımcılığı tutum ölçeğinin geliştirilmesi ve psikometrik değerlendirmesi. Türk Geriatri Dergisi, 2011; 14(3): 259-268.

35. Sources of images used in figures. 2019. URL: https://thenounproject.com/. June 302019.

36. Armitage R, Laura BN. COVID-19 and the consequences of isolating the elderly. The Lancet Public Health. 2020; 5(5): e256. https://doi.org/10.1016/S2468-2667(20)30061-X.

37. Van Wicklin SA. Ageism in Nursing. Plastic Surgical Nursing. 2020; 40(1): 20-24. doi: https://doi.org/10.1097/PSN.0000000000000290.

38. Rahayuwati L, Nuriyanto A, Agustina HS, Susanti RD, Pramukti I. COVID-19 in indonesia social epidemiology perspective tailored to community-based health promotion. Journal of Talent Development and Excellence. 2020; 12(1): 2512-2524.

39. Asghari F, Parsapour A, Gooshki ES. Priority Setting of Ventilators in the COVID-19 Pandemic from the public's perspective. medRxiv. 2020. https://doi.org/10.1101/2020.06.10.20127290.

40. Kuwahara K, Kuroda A, Fukuda Y. COVID-19: Active measures to support community-dwelling older adults. Travel Medicine and Infectious Disease 2020; 101638. https://doi.org/10.1016/j.tmaid.2020.101638.

41. Yang Y, Li W, Zhang Q, Zhang L, Cheung T, Xiang YT. Mental health services for older adults in China during the COVID-19 outbreak. Lancet Psychiatry. 2020;7(4):e19. https://doi.org/10.1016/S2215-0366(20)30079-1

42. Vieira CM, Franco OH, Restrepo GC, Abel T. COVID-19: The forgotten priorities of the pandemic. Maturitas. 2020; 136: 38-41 https://doi.org/10.1016/j.maturitas.2020.04.004.

43. da Silva Santos S, Brandão GCG, Araújo KMDFA. Social isolation: a look health elderly mental during the COVID-19 pandemic. Research, Society and Development. 2020; 9(7): 1-15. https://doi.org/10.33448/rsdv9i7.4244

44. Banskota S, Healy M, Goldberg EM. 15 Smartphone apps for older adults to use while in isolation during the covid19 pandemic. Western Journal of Emergency Medicine 2020; 21(3): 514-525. doi: https://doi.org/10.5811/westjem.2020.4.47372.

45. Verbeek H, Gerritsen DL, Backhaus R, de Boer BS, Koopmans RT, Hamers JP. Allowing visitors back in the nursing home during the COVID-19 crisis-A Dutch national study into first experiences and impact on well-being. Journal of the American Medical Directors Association. 2020. https://doi.org/10.1016/j.jamda.2020.06.020.

46. Mehra A, Rani S, Sahoo S, Parveen S, Singh AP, Chakrabarti S, Grover S. A crisis for elderly with mental disorders: Relapse of symptoms due to heightened anxiety due to COVID-19. Asian Journal of Psychiatry. 2020; 51:102114. https://doi.org/10.1016/j.ajp.2020.102114.

47. Brooke J, Jackson D. Older people and COVID- 19: Isolation, risk and ageism. Journal of clinical nursing. 2020. https://doi.org/10.1111/jocn.15274.

48. Voogt SJ, Mickus M, Santiago O, Herman SE. Attitudes, experiences, and interest in geriatrics of first- year allopathic and osteopathic medical students. Journal of the American Geriatrics Society. 2008; 56(2): 339-344. https://doi.org/10.1111/j.1532-5415.2007.01541.x.

49. Lippi G, Henry BM, Sanchis-Gomar F. Physical inactivity and cardiovascular disease at the time of coronavirus disease 2019 (COVID-19). European Journal of Preventive Cardiology. 2020; 27(9): 906-908. https://doi.org/10.1177/2047487320916823.

50. Edmonds JK, Kneipp SM, Campbell L. A call to action for public health nurses during the COVID- 19 pandemic. Public Health Nursing. 2020; 37(3): 323-324. https://doi.org/10.1111/phn.12733. 